\title{
Гипотетическая позднекарельская тектоника юго-восточной части Кольского полуострова
}

Подурушин В.Ф.

РГУНГ им. И.М. Губкина, Москова, vfр53@mail.ru

\begin{abstract}
Аннотация. В статье излагается авторская гипотеза, основанная на рассмотрении современного рельефа Кольского региона и контуров окружающих его морских бассейнов. Предполагается, что в конце позднекарельской эры за счет плавления нижней коры и гранитизации средней- низов верхней коры образовалась Восточно-Кольская кольцевая структура. Очаг плавления был связан с растяжением пассивной окраины формировавшегося континента Балтия. Монолитная кора кольцевой структуры ограничивала развитие рифейского и палеозойского рифтогенеза и магматизма, а в позднем кайнозое определила конфигурацию Кольского полуострова, Белого моря и мощность четвертичных отложений.

Ключевые слова: тектоника, поздний карелий, Восточно-Кольская кольцевая структура, Балтия, рифей, рифтогенез, Белое море, неотектоника.
\end{abstract}

\section{Hypothetical Late Karelian tectonics of the South-Eastern part of Kola Peninsula}

Podurushin V.F.

Gubkin Russian State University of Oil and Gas, Moscow,vfp53@mail.ru

\begin{abstract}
The article presents the author's hypothesis based on the consideration of the modern relief of the Kola region and the contours of the surrounding sea basins. It is assumed that the East Kola ring structure formed at the end of the late Karelian era due to the melting of the lower crust and granitization of the middle-lower upper crust. The melting hearth was associated with the stretching of the growing Baltica continent passive margin. The ring structure monolithic crust limited the development of the Riphean and Paleozoic rifts and magmatism. In Late Cenozoic it determined the White Sea configuration and the Quaternary sediments thickness.
\end{abstract}

Key words: tectonics, Late Karelian, East Kola ring structure, Baltica, Riphean rifts, Paleozoic magmatism, White Sea, neotectonics.

На космических снимках и географических картах Кольского полуострова отчетливо видна почти правильная полукруглая форма его юго-восточного побережья в Горле и Воронке Белого моря. Далее эта дуга выходит на сушу и продолжается на юго-западе по нижнему течению p. Варзуга, на западе и северо-западе - по водоразделу, с одной стороны которого реки текут на северовосток (Воронья, Лица), с другой - на восток и юго-восток (Иоканга, Поной, Варзуга). Судя по геоморфологическим признакам, на севере описываемая дуга срезается субширотным разломом, определяющим также северные границы Хибинского и Ловозерского щелочных массивов и изгиб всей Хибино-Контозерской дизъюнктивной зоны. Таким образом, по гидролого-геоморфологическим признакам вырисовывается кольцевая структура (КС) диаметром около 230 км, которая ниже называется Восточно-Кольской (рис. 1). Ее существование подтверждается рельефом поверхности коренных пород и мощностью четвертичных отложений в акватории пролива Горло и на прилегающей территории. Дневная поверхность Восточно-Кольской КС имеет общий наклон к юго-востоку; диаметр, совпадающий с линией падения, проходит по долине верхнего-среднего течения р. Поной и по р. Снежница до одноименной губы Белого моря. Ранее фрагментарные дугообразные сбросы в проливе Горло уже изображались некоторыми авторами (Балуев и др., 2000).

Указанная территория образует ядро КС, которое обрамляется двумя нечетко выраженными дугообразными фрагментами внешней зоны в Горле-Воронке Белого моря и в междуречье Варзуги и Умбы. Скорее всего, внешняя зона отражает пассивную реакцию обрамления на тектоническое воздействие ядра структуры. Для ее более подробной характеристики материалов недостаточно, поэтому в дальнейшем изложении она не рассматривается, а под термином «кольцевая структура» подразумевается только ядро. 
Мощность «гранулито-базитового» мегаслоя коры КС редуцирована, «гранитно-метаморфический» мегаслой аномально утолщен (Государственная..., 2001). По расчетным данным В.Н. Глазнева (Глазнев, 2003), кольцевая структура на срезе -10 км отчетливо выделяется на окру-

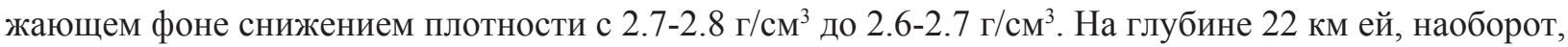
отвечает повышение плотности до 2.9-3.0 г/ $\mathrm{cm}^{3}$ по сравнению с расположенными западнее кристал-

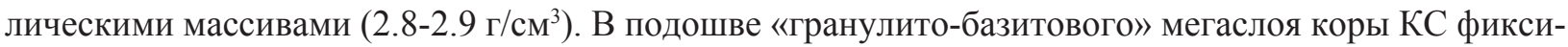
руется увеличение скорости сейсмических волн, которое относительно быстро исчезает вниз и более постепенно - вверх по разрезу (Глазнев, 2003).

Перечисленные свойства Восточно-Кольской структуры позволяют предполагать в качестве механизма ее формирования частичное плавление «гранулито-базитового» мегаслоя. Образовавшиеся при этом легкоплавкие и легкие сиалические выплавки поднимались вверх по разрывным нарушениям, очевидно, находившимся в тот период в состоянии растяжения. В результате произошла гранитизация кровли «гранулито-базитов», а также прилегающей части «гранитно-метаморфического» мегаслоя. Возможно, апикальная часть этого магматического ареала выведена на поверхность в виде Стрельнинского гранитного массива, сформировавшегося при анатексисе на глубине свыше 5-7 км из водонасыщенных расплавов при температуре $340-700^{\circ} \mathrm{C}$ (Государственная..., 2001). Под совокупным воздействием перечисленных процессов земная кора была консолидирована почти на полную мощность.
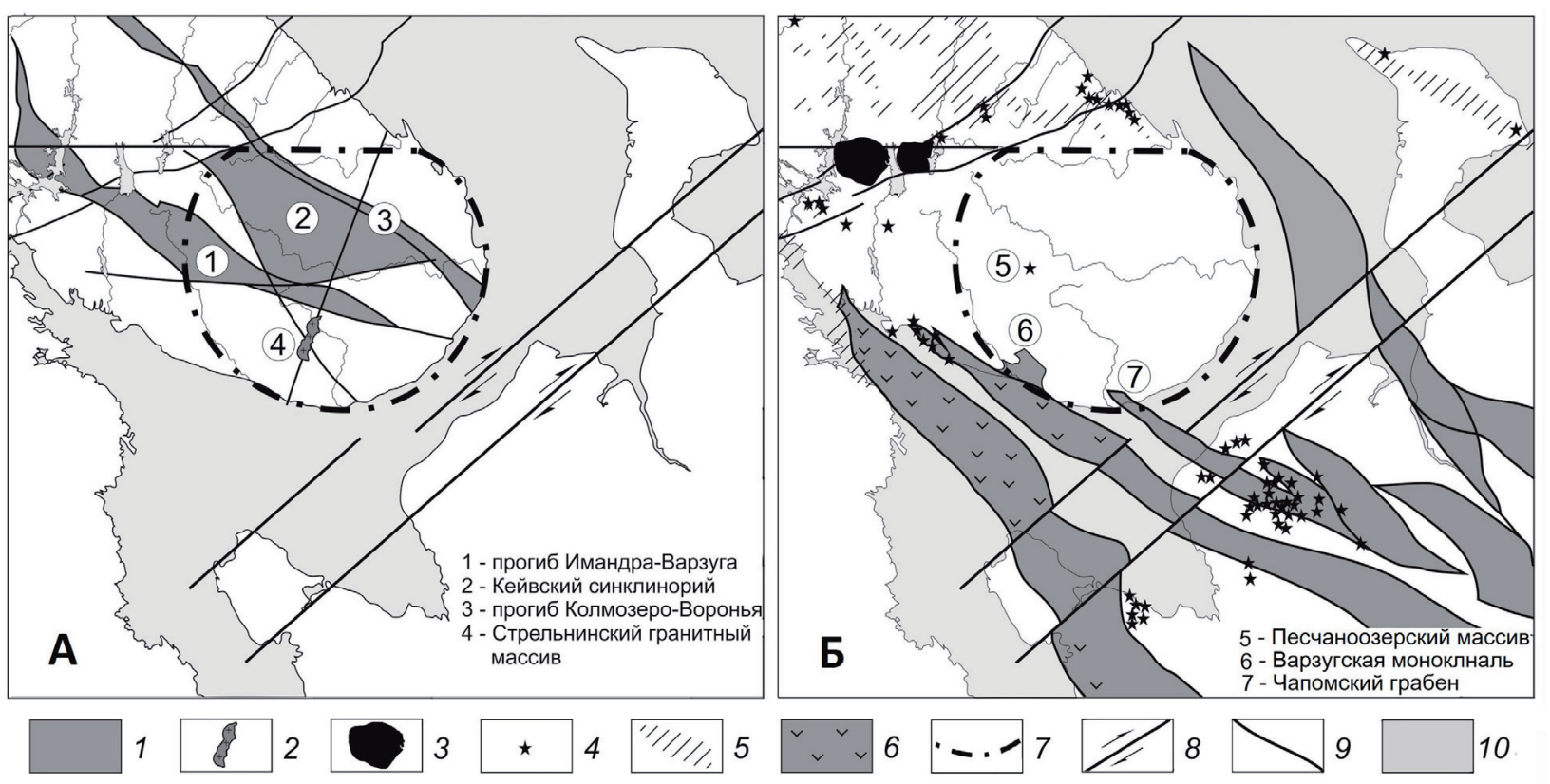

Рис. 1. Взаимоотношения Восточно-Кольской КС с раннедокембрийскими

(А) и рифейско-палеозойскими (Б) структурами Кольско-Беломорского региона.

1 - раннедокембрийские прогибы и синклинории; 2 - Стрельнинский гранитный массив; 3 - Хибинский и Ловозерский палеозойские интрузивные массивы; 4 - мелкие рифейские и палеозойские интрузии и трубки взрыва; 5 - области развития рифейских и палеозойских даек; 6 - области распространения рифейских вулканогенных пород; 7 - контур Восточно-Кольской кольцевой структуры; 8 - Беломоро-Вайгачская сдвиговая зона; 9 - прочие разломы; 10 - акватории.

Fig. 1. Relations between the East Kola ring structure and the Early Precambrian

(A) and Riphean-Paleozoic (B) structures of Kola-White Sea region.

1 - Early Precambrian depressions, and synclinorium; 2 - Strel'ninskiy granitic massif; 3 - Khibiny and Lovozero Paleozoic intrusios; 4 - small Riphean and Paleozoic intrusions and diatremes; 5 - areas of the Riphean and Paleozoic dikes development; 6 - areas of the Riphean volcanic rocks distribution; 7 - East Kola ring structure contour; 8 - the White Sea-Vaigatch shear zone; 9 - other faults; 10 - water areas. 
Возраст кольцевой структуры оценивается по следующим данным.

Восточно-Кольская КС пересекает границы крупнейших раннедокембрийских образований (прогибы Колмозеро-Воронья, Имандра-Варзуга, Кейвский синклинорий и огранивающие их разломы северо-западного простирания (Государственная..., 2003)). Внутри кольцевой структуры сходятся крупные раннедокембрийские дизъюнктивные зоны северо-западного (Южно-Имандровская, Северо-Кейвская), субширотного (Южно-Понойская) и северо-восточного (Стрельнинско-Святоносская) простирания (рис. 1 А). Таким образом, складывается впечатление, что архейско-раннепротерозойские структуры существовали до образования кольцевой структуры и определили ее положение в узле пересечения крупнейших дизъюнктивов. Времени появления Восточно-Кольской КС может соответствовать изотопный возраст гранитов Стрельнинского массива, составляющий около 1830 млн. лет (Государственная..., 2001).

Рифейские и палеозойские структурно-вещественные комплексы по отношению к ВосточноКольской КС ведут себя иначе (рис. 1 Б). Средне-позднерифейские грабены обрамляют ее со стороны Белого моря или заканчиваются на границе ядра. Лишь единичные мелкие апофизы незначительно внедряются внутрь окружности, где быстро выклиниваются (Варзугская моноклиналь, Чапомский грабен). Почти все рифейские и палеозойские интрузии (за исключением Песчаноозерского массива), все дайки, трубки взрыва и вулканогенные толщи авлакогенов расположены в обрамлении КС. Следовательно, начиная с рифея, кольцевая структура вела себя как малопроницаемое тело, ограничивавшее распространение процессов тектоно-магматической активизации и размещение изверженных пород. В среднем рифее разрастающиеся континентальные рифты, огибая этот жесткий массив с юго-запада, отодвинули его от основного тела Восточно-Европейского кратона с компонентой вращения против часовой стрелки (Подурушин, 2016).

По совокупности данных можно полагать, что Восточно-Кольская кольцевая структура образовалась в позднекарельскую эру.

В это время заканчивалось формирование Восточно-Европейского кратона, одной из составных частей которого была малая континентальная плита Фенноскандия (Bogdanova et al., 2008). На ее активной юго-западной окраине вследствие аккреции островных дуг и микроконтинентов возник Свекофеннский складчато-надвиговый пояс, а противоположная, северо-восточная окраина развивалась в пассивном режиме, для которого характерна обстановка общего умеренного растяжения. В такой геодинамической ситуации узел пересечения древних разломов, существовавший в юго-восточной половине Кольского полуострова, превратился в область декомпрессии и частичного плавления нижней коры, над которым по описанному выше механизму образовалась ВосточноКольская кольцевая структура. Гранитные тела, выплавлявшиеся и кристаллизовавшиеся в относительно спокойной тектонической обстановке, спаяли разнородные блоки внутри кольцевого разлома и превратили этот объем в относительно монолитное тело, которое реагировало на последующие внешние воздействия как единое целое. В частности, на неотектоническом этапе латеральное давление со стороны раскрывающейся Северной Атлантики в сочетании с вертикальными знакопеременными гляциоизостатическими нагрузками привело к некоторому подъему северо-западного сектоpa КС, сопоставимому погружению ее юго-восточного сектора и образованию во внешней зоне Воронки и Горла Белого моря.

В силу малой проницаемости коры Восточно-Кольской КС эндогенные полезные ископаемые рифейско-кайнозойского возраста на ее площади следует связывать главным образом с контактовой зоной ядра. Однако наличие Песчаноозерского щелочно-ультраосновного массива свидетельствует о возможном присутствии отдельных рудных скоплений в локальных флюидных ловушках внутри ядра.

\section{Литература}

1. Балуев А.С., Моралев В.М., Глуховский М.З., Пржиялговский Е.С., Терехов Е.Н. Тектоническая эволюция и магматизм Беломорской рифтовой системы // Геотектоника. 2000. № 5. С. 30-43.

2. Глазнев В.Н. Комплексные геофизические модели литосферы Фенноскандии. Апатиты. Изд-во: КНЦ PAH. 2003. $252 \mathrm{c}$. 
3. Государственная геологическая карта Российской Федерации. Масштаб 1:1000000 (новая серия). Лист Q-(35)-37 (Кировск) (ред. Ю.Б. Богданов). СПб.Изд-во: ВСЕГЕИ. 2003. 2 л.

4. Государственная геологическая карта Российской федерации. Масштаб 1:1000000 (новая серия). Лист Q-(35)-37 (Кировск). Объяснительная записка (отв. ред. К.Э. Якобсон). СПб. Изд-во: МПР России. ВСЕГЕИ. 2001. 268 с.

5. Подурушин В.Ф. Геодинамика формирования среднерифейской Кольско-Мезенской рифтовой системы (север европейской России) // Тектонофизика и актуальные вопросы наук о Земле. Материалы IV тектонофизической конференция. М. Изд-во: ИФЗ РАН. 2016. С. 194-199.

6. Bogdanova S.V., Bingen B., Gorbatschev R., Kheraskova T.N., Kozlov V.I., Puchkov V.N. \& Voloz Yu.A. The East European Craton (Baltica) before and during the assembly of Rodinia // Precambrian Res. 2008. V. 160. Is. 1-2. P. 23-45. 